\title{
The no-tillage, with crop rotation or succession, can increase the degree of clay dispersion in the superficial layer of highly weathered soils after 24 years
}

\section{O plantio direto, com rotação ou sucessão, pode aumentar o grau de argila dispersa na camada superficial de solos altamente intemperizados depois de 24 anos}

\author{
Alex Figueiredo ${ }^{1 *}$; Thadeu Rodrigues de Melo ${ }^{1 ;}$ Jean Carlo Santos de Oliveira ${ }^{1 ;}$ \\ Wesley Machado'; José Francirlei de Oliveira2; ${ }^{2}$ Julio Cezar Franchini3; \\ Henrique Debiasi ${ }^{3}$; Maria de Fátima Guimarães ${ }^{4}$
}

\section{Highlights}

No-tillage was the soil management system with the highest cay dispersion values.

Crop rotation did not reduce clay dispersion when compared to succession.

The agricultural implements provided the same values of clay dispersion.

$\mathrm{H}+\mathrm{Al}$ was the only chemical attribute that affected clay dispersion.

\begin{abstract}
Clay dispersion is directly related to water erosion, especially during detaching and dragging of particles. No-till is one of the most important strategies for soil and water conservation in tropical and sub-tropical regions, and when associated with crop rotation, may reduce the degree of clay dispersion. The study aimed to evaluate, after 24 years, the effect of different soil management systems and crop systems on the degree of clay dispersion of a Rhodic Ferralsol. The experimental design was completely randomized in a $4 \times 2$ factorial scheme, with four soil managements (continuous no-tillage, no-tillage with chiseling every three years, disk plowing followed by light harrowing and heavy disking followed by light harrowing) and with two crop systems (crop succession and rotation). The degree of clay dispersion was evaluated and associated with soil chemical attributes from layer 0.00-0.10 $\mathrm{m}$. The degree of clay dispersion is affected by the soil

1 Discentes do Curso de Doutorado do Programa de Pós-Graduação em Agronomia, Universidade Estadual de Londrina, UEL, Londrina, PR, Brasil. E-mail: alexkdn@hotmail.com; thadeurodrigues@hotmail.com; jeancarlo_agro@ hotmail.com; w.machado@agronomo.eng.br

2 Dr., Analista em Ciência e Tecnologia, Instituto de Desenvolvimento Rural do Paraná, IDR, Paraná, Londrina, PR, Brasil. E-mail: jfoliveira79@iapar.br

${ }^{3}$ Pesquisadores, Empresa Brasileira de Pesquisa Agropecuária, EMBRAPA Soja, Londrina, PR, Brasil. E-mail: julio. franchini@embrapa.br; henrique.debiasi@embrapa.br

${ }^{4}$ Prof $^{\mathrm{a}} \mathrm{Dr}^{\mathrm{a}}$, Departamento de Agronomia, Programa de Pós-Graduação em Agronomia, UEL, Londrina, PR, Brasil. E-mail: mfatima@uel.br

* Author for correspondence
\end{abstract}

Received: Mar. 04, 2020 - Approved: Oct. 30, 2020 
management systems with no effect of crop systems. The soil management system with the lowest soil disturbance (continuous no-tillage) has a higher degree of clay dispersion than the ones that disturb the soil, regardless of the agricultural implement used or soil disturbance intensity. The soil electrochemical imbalance, primarily caused by soil potential acidity, is positively correlated to the increase in the degree of clay dispersion of the superficial soil layer under continuum no-tillage.

Key words: Rhodic Ferralsol. Soil management. Crop systems. Conventional tillage.

\section{Resumo}

A argila dispersa está diretamente relacionada com a erosão hídrica, especialmente durante o desprendimento e arraste de partículas. O plantio direto é uma das mais importantes estratégias para conservação do solo e da água nas regiões tropical e sub-tropical, e quando associado com a rotação de culturas, pode reduzir o grau de dispersão de argila. O objetivo desse estudo foi avaliar, após 24 anos, o efeito de diferentes sistemas de manejo e de culturas no grau de dispersão de argila de um Latossolo Vermelho. $\mathrm{O}$ delineamento experimental foi inteiramente casualizado em um esquema fatorial $4 \times 2$, com quatro manejos do solo (plantio direto contínuo, plantio direto com escarificação a cada três anos, aração de discos seguida de gradagem leve e gradagem pesada seguida de gradagem leve) e dois sistemas de cultivo (sucessão de cultura e rotação). O grau de dispersão da argila foi avaliado e associado aos atributos químicos do solo da camada 0,00-0,10 m. O grau de dispersão da argila é afetado pelos sistemas de manejo do solo sem efeito dos sistemas de cultivo. O sistema de manejo de solo com menor perturbação do solo (plantio direto contínuo) possui o maior grau de dispersão de argila do que os que perturbam o solo, independentemente do implemento agrícola utilizado ou da intensidade do distúrbio do solo. O desequilíbrio eletroquímico do solo, causado principalmente pela acidez potencial do solo, está positivamente correlacionado ao aumento do grau de dispersão de argila da camada superficial do solo sob plantio direto contínuo.

Palavras-chave: Latossolo Vermelho. Manejo do solo. Sistemas de culturas. Plantio convencional.

\section{Introduction}

Conservation agriculture is practiced at around 100 Mha of land in the world (Federação Brasileira de Plantio Direto e Irrigação [FEBRAPD], 2020), which represents just over $6 \%$ of the 1,500 Mha of arable land in the world (Food and Agriculture Organization of the United Nations [FAO], 2001). Most areas which operate in the conservation system are in North and South America (FAO, 2001). It makes grain production viable and reduces the need for agricultural inputs and the climatic risks caused by agriculture (Findlater, Kandlikar, \& Satterfield, 2019). In this context, no-till is one of the most important strategies for soil and water conservation in tropical and subtropical regions (Derpsch, Friedrich, Kassam, \& Hongwen, 2010).

In Brazil, more than 32 Mha of soil are managed under a no-tillage system, which corresponds to more than $85 \%$ of the temporary crop areas in the country (Kassam, Friedrich, \& Derpsch, 2019). The benefits of no-till to the chemical, physical and biological qualities of the soil have been extensively documented in the literature (Singh, Phogat, Dahiya, \& Batra, 2014; Pittelkow et al., 2015; Munkholm, Heck, Deen, \& Zidar, 2016), especially when 
associated with crop rotation (Palm, BlancoCanqui, De Clerck, Gatere, \& Grace, 2014), thus significantly reducing the production of sediments and soil erosion (Merten \& Minella 2013). However, this conservationist system involves a continuous and complex process of agricultural technologies that are partially adopted by farmers or extension agents (FAO, 2001; Merten, Araújo, Biscaia, Barbosa, \& Conte, 2015). The partiality in the adoption of no-till can be observed in the farmers that have adopted a poor crop diversity for straw management (Merten et al., 2015) and increased the frequency of agricultural implements use such as the chisel and the disc harrow to incorporate fertilizers (Auler et al., 2019) and to destroy superficial crusts caused by the absence of soil revolvement (Camara \& Klein, 2005).

Clay dispersion has been used to evaluate the effects of different uses and management systems in Oxisols (Tavares, Barbosa, \& Ribon, 2010; Barbosa, Oliveira, Miyazawa, Ruiz, \& Tavares; 2015; Melo, Telles, Machado, \& Tavares, 2016; Machado, Melo, \& Tavares, 2017) or other soil types (Abdollahi, Schjonning, Elmholt, \& Munkholm, 2014; Lipiec, Czyżb, Dexter, \& Siczeka, 2018; Rengasamy, Tavakkoli, \& Mcdonald, 2016; Getahun, Munkholm, \& Schjonning, 2016). Clay dispersion is directly related to the stability of the microstructure, and the erosive processes (Igwe \& Udegbunam, 2008; Igwe \& Obalum, 2013). The increase in clay dispersion potentiates the formation of surface crusts, reducing infiltration capacity and hydraulic conductivity of the soil, and can still be easily transported to water bodies (Nguetnkam \& Dultz, 2014; Didoné, Minella, \& Merten, 2015).

Increased levels of dispersed clay and problems of soil degradation and erosion in no-till areas have recently been reported in the literature (Merten et al., 2015; Didoné et al., 2014, 2015; Telles, Righetto, Costa, Volsi, \& Oliveira, 2019). Hence, the hypothesis presented is that a conservationist no-tillage system should associate crop rotation and the absence of soil revolving to reduce the dispersed clay content of the surface layer and, consequently, the potential for degradation of these areas, compared to other systems with soil revolving and low crop diversity.

This study aimed to evaluate, after 24 years, the effect of different soil management and crop systems on the degree of clay dispersion of a Rhodic Ferralsol.

\section{Material and Methods}

\section{Experimental area}

Before the installation of the experiment, the area was planted with coffee (Coffea arabica L.) for approximately 40 years. The experiment was installed in the $1988 / 1989$ crop year, at the experimental station of the Brazilian Agricultural Research Corporation (Empresa Brasileira de Pesquisa Agropecuária - EMBRAPA) - National Soybean Research Center (Centro Nacional de Pesquisa de Soja - CNPS), located $\left(23^{\circ} 11^{\prime} \mathrm{S}, 51^{\circ} 11^{\prime} \mathrm{W}\right)$ in the municipality of Londrina (PR). The area has an average altitude of $620 \mathrm{~m}$, the regional climate is mesothermal humid subtropical (Cfa) according to the Köppen-Geiger climate classification, with an average annual rainfall of $1,651 \mathrm{~mm}$. The average precipitation is $217 \mathrm{~mm}$ in January, the wettest month, and $60 \mathrm{~mm}$ in August, the driest month. The experiment was installed on a Latossolo Vermelho distroférrico (Santos et al., 2013) (Rhodic Ferralsol (IUSS Working Group WRB, 2015)), with $760 \mathrm{~g} \mathrm{~kg}^{-1}$ clay, $170 \mathrm{~g} \mathrm{~kg}^{-1}$ silt, and $70 \mathrm{~g} \mathrm{~kg}^{-1}$ sand. 


\section{Experimental design and treatments}

To install the experiment, the area was divided into experimental units $7.5 \mathrm{~m}$ wide by $30 \mathrm{~m}$ long $\left(225 \mathrm{~m}^{2}\right)$. The experimental design was completely randomized, with four replicates, in a $4 \times 2$ factorial design, with four soil managements and two crop systems.

The following soil managements were used: Continuous no-tillage (NT), in which sowing is performed over residues of the previous crop, opening only a furrow in the sowing row; No-tillage with chiseling (NTC), in which the soil is chiseled every 3 years in the winter, using a chisel plow with five shanks $0.35 \mathrm{~m}$ apart, working at a depth of $0.25 \mathrm{~m}$, without soil leveling operations; Conventional tillage with disk plowing (DP) with 6-inch disc blades at a mean depth of $0.20 \mathrm{~m}$, followed by light harrowing, working at a depth of $0.08 \mathrm{~m}$; Conventional tillage with heavy disking (HD) with 24-inch blades working at a mean depth of $0.15 \mathrm{~m}$ followed by light harrowing at 0.08 $m$ of depth. In DP and HD, tillage is performed every year before the summer crops and before the winter crops with heavy disking, at approximately $0.15 \mathrm{~m}$, followed by light harrowing, at a depth of $0.08 \mathrm{~m}$. In the NTC treatment, chiseling was performed for the last time three years before sampling the soil for the study.

The following crop systems were evaluated: Succession, with common wheat (Triticum aestivum L.) in the winter and soybean (Glycine max L. Merr.) in the summer; Rotation, in 4-year cycles, with the following species in the winter-summer: white lupin (Lupinus albus L.) - corn (Zea mays L.); black oat (Avena strigosa Schreb.) - soybean; common wheat soybean; common wheat - soybean.

\section{Experiment}

Since the installation of the experiment, every three years, limestone has been applied to reach $60 \%$ base saturation and to adjust the $\mathrm{pH}$ in water to 5.5, applying limestone for the last time in the $2012 / 2013$ crop year. The fertilizers were applied simultaneously at 0.05 $\mathrm{m}$ below and beside the seeds, during sowing.

Throughout the experiment, soybean seeds have been inoculated with Bradyrhizobium japonicum and B. elkanii, adding, on average, $47 \mathrm{~kg} \mathrm{ha}^{-1} \mathrm{P}$ (triple superphosphate) and $41.2 \mathrm{~kg} \mathrm{ha}^{-1} \mathrm{~K}^{+}$(potassium chloride), without mineral nitrogen fertilization. After growing soybean for 10 years, $20 \mathrm{~g} \mathrm{ha}^{-1}$ Mo (sodium molybdate) and $2 \mathrm{~g} \mathrm{ha}^{-1} \mathrm{Co}$ (cobalt chloride) have been added to the soil annually. In the 1998/1999 and 2000/2001 crop years, the soybean crop was not fertilized. For the corn and common wheat crops, an average of 19.2 and $16.4 \mathrm{~kg} \mathrm{ha}^{-1} \mathrm{~N}$ (urea), 51.5 and $57.5 \mathrm{~kg}$ ha ${ }^{-1} \mathrm{P}$ (triple superphosphate), and 47 and 32.3 $\mathrm{kg} \mathrm{ha}^{-1} \mathrm{~K}^{+}$(potassium chloride) were added, respectively, each year. For cover crops, no fertilizer was added.

Since the beginning of the experiment, plots grown with common wheat and winter cover crops (white lupin or black oat) were sown in April. Conversely, summer crops (soybean and corn) were sown in November.

Sowing, crop management, and weed, pest, and disease control were performed according to the technical recommendations for growing soybean, corn, and common wheat and were the same for all treatments. In the NT system, before sowing, the weeds were desiccated using glyphosate. After sowing, other herbicides were applied in the DP treatment as needed. 


\section{Sample and laboratory procedures}

Disturbed soil samples were collected from the 0.00-0.10 m layer, in the 2012/2013 crop year, after the soybean harvest, 24 years after starting the experiment. Until the collection period, six cycles of 4 years of crop rotation were performed. The samples were air-dried and sieved through a 2-mm mesh (air-dried fine earth - ADFE) for chemical and physical analysis.

The chemical analyses were performed according to the methods described by (Pavan, Bloch, Zemoulski, Miyazawa, \& Zocoler, 1992), determining the following parameters: $\mathrm{pH}\left(\mathrm{CaCl}_{2}\right) 1 \mathrm{~mol} \mathrm{~L}-1 ; \mathrm{pH}\left(\mathrm{H}_{2} \mathrm{O}\right) ; \mathrm{pH}(\mathrm{KCl}) 1 \mathrm{~mol}$ $\mathrm{L}^{-1}$; exchangeable acidity $\left(\mathrm{Al}^{3+}\right)$ in $\mathrm{KCl}(1 \mathrm{~mol}$ $\left.\mathrm{L}^{-1}\right)$ assessed by titration with $\mathrm{NaOH}(0.01$ mol $\left.\mathrm{L}^{-1}\right)$; soil potential acidity $(\mathrm{H}+\mathrm{Al})$ using the Shoemaker-McLean-Pratt (SMP) buffer test; exchangeable calcium $\left(\mathrm{Ca}^{2+}\right)$ and magnesium $\left(\mathrm{Mg}^{2+}\right)$ extracted with $1 \mathrm{~mol} \mathrm{~L}^{-1} \mathrm{KCl}$ and titrated with EDTA; available phosphorus (P) and exchangeable potassium $\left(\mathrm{K}^{+}\right)$assessed by Mehlich-1 extraction and reading on a spectrophotometer at $630 \mathrm{~nm}$ and a flame photometer, respectively; total organic carbon (TOC) determined by Walkley-Black, with oxidation by $\mathrm{Cr}_{2} \mathrm{H}_{2} \mathrm{O}_{7}$ and titration with $\mathrm{FeSO}_{4}$ The total cation exchange capacity (CEC) and $\Delta \mathrm{pH}\left(\Delta \mathrm{pH}=\left(\mathrm{pH}(\mathrm{KCl})\left(1 \mathrm{~mol} \mathrm{~L}^{-1}\right)-\mathrm{pH}\left(\mathrm{H}_{2} \mathrm{O}\right)\right.\right.$ were also calculated in this study.

The physical analyses were performed according to the methods described by (Claessen, Barreto, Paula, \& Duarte, 1997). The granulometry was determined using 20 $g$ of ADFE and the pipette method with slow stirring, at $180 \mathrm{rpm}$ for 16 hours as mechanical dispersant and with $\mathrm{NaOH} 1 \mathrm{~mol} \mathrm{~L}^{-1}$ as chemical dispersant. The degree of clay dispersion (DCD) was calculated after determining the disperse clay using the same method, albeit without adding sodium hydroxide, that is, only using mechanical dispersion, based on the following equation: $\operatorname{DCD}(\%)=$ disperse clay * 100 / total clay.

\section{Statistical procedures}

After determining the homogeneity of variance and normality of the residuals using the Bartlett and Shapiro - Wilk tests, respectively, the data were subjected to factorial analysis (four soil managements $x$ two crop systems), and when presenting a significant $p$-value $(P$ $<0.05)$, the data were subjected to the least significant difference (LSD) test with 5\% probability to observe differences between the means of treatments and DCD. Multiple regression analysis was also performed between the chemical attributes (TOC, $\mathrm{Ca}^{2+}$, $\mathrm{Mg}^{2+}, \mathrm{Al}^{3+}, \mathrm{P}, \mathrm{K}^{+}, \mathrm{H}+\mathrm{Al}, \mathrm{CEC}, \mathrm{pH}\left(\mathrm{CaCl}_{2}\right)$ and $\left.\Delta \mathrm{pH}\right)$ and the DCD, using the Stepwise method to identify those that effectively affected the DD.

All statistical tests were performed using the software R and the packages "mass", "agricolae", "ExCNTs.pt" and "rcmdr".

\section{Results}

Factorial analysis between crop systems (crop rotation and succession), soil management (HD, DP, NTC, and NT), and the interaction of both variables (Table 1) shows that DCD was only affected by the different soil management. 
Table 1

Factorial analysis of the degree of clay dispersion (DCD), for crop systems and soil management in the 0.00-0.10 m layer

\begin{tabular}{|ccccc|}
\hline & DF & MS & F & Sig. \\
\hline Soil management (SM) & 3 & 123.66 & 11.2 & $<0.01^{*}$ \\
Crop systems (CS) & 1 & 0.36 & 0.03 & 0.86 \\
\hline SM * CS & 3 & 24.74 & 2.24 & 0.11 \\
Error & 24 & 11.04 & &
\end{tabular}

*Significant at $5 \%$.

The mean comparison test between soil management (Table 2) showed that NT had a higher DCD than soil management with soil disturbance (NTC, DP, and HD), with no significant differences between these soil management.

Similarly to DCD, the chemical attributes were influenced only by soil management, without influence from either crop systems or interaction of these factors (Table 3). The soil chemical analyses showed that, after 24 years of management, the values of TOC, CEC macronutrients $\left(\mathrm{Ca}^{2+}, \mathrm{Mg}^{2+}\right.$ e K+), and $\mathrm{pH}\left(\mathrm{CaCl}_{2}\right)$ were higher in the NT. Furthermore, the system presented the lowest value of $\mathrm{H}+\mathrm{Al}$ (Table 3). The CEC values decreased with the increase in soil disturbance (Table 3).

Multiple regression analyses between these chemical properties and DCD resulted in the following function: $\hat{y}=120.259^{* *}$ (7.703** $\mathrm{H}+\mathrm{Al}$ ), with $\mathrm{R}^{2}=0.55$ (Eq. 1), where the increase of $\mathrm{H}+\mathrm{Al}$ decreased the values of $\mathrm{DCD}$.

\section{Table 2}

Degree of clay dispersion (DCD, \%), in the $\mathbf{0 . 0 0 - 0 . 1 0 ~ m ~ l a y e r ~ i n ~ r o t a t i o n ~ a n d ~ s u c c e s s i o n ~ c r o p ~ s y s t e m s , ~}$ and soil managements: heavy disking (HD), disk plowing (DP), no-tillage with chiseling (CNT), and continuous no-tillage (NT)

\begin{tabular}{ccccccc|} 
Soil management & \multicolumn{7}{c|}{ Crop systems } \\
\cline { 2 - 7 } & Rotation & C.V. & Succession & C.V. & Mean & C.V. \\
DP & 80.66 & 3.20 & 84.21 & 3.05 & 82.43 B & 3.80 \\
HD & 84.44 & 3.49 & 83.88 & 4.52 & 84.16 B & 4.05 \\
NTC & 84.21 & 2.39 & 79.81 & 3.37 & $82.01 \mathrm{~B}$ & 3.95 \\
NT & 89.38 & 2.40 & 91.63 & 4.08 & $90.51 \mathrm{~A}$ & 3.59 \\
Mean & $84.67 \mathrm{a}$ & - & $84.88 \mathrm{a}$ & - & - & -
\end{tabular}

Different letters, uppercase in columns and lowercase in rows, indicate significant differences according to the LSD test at a $5 \%$ probability level. 


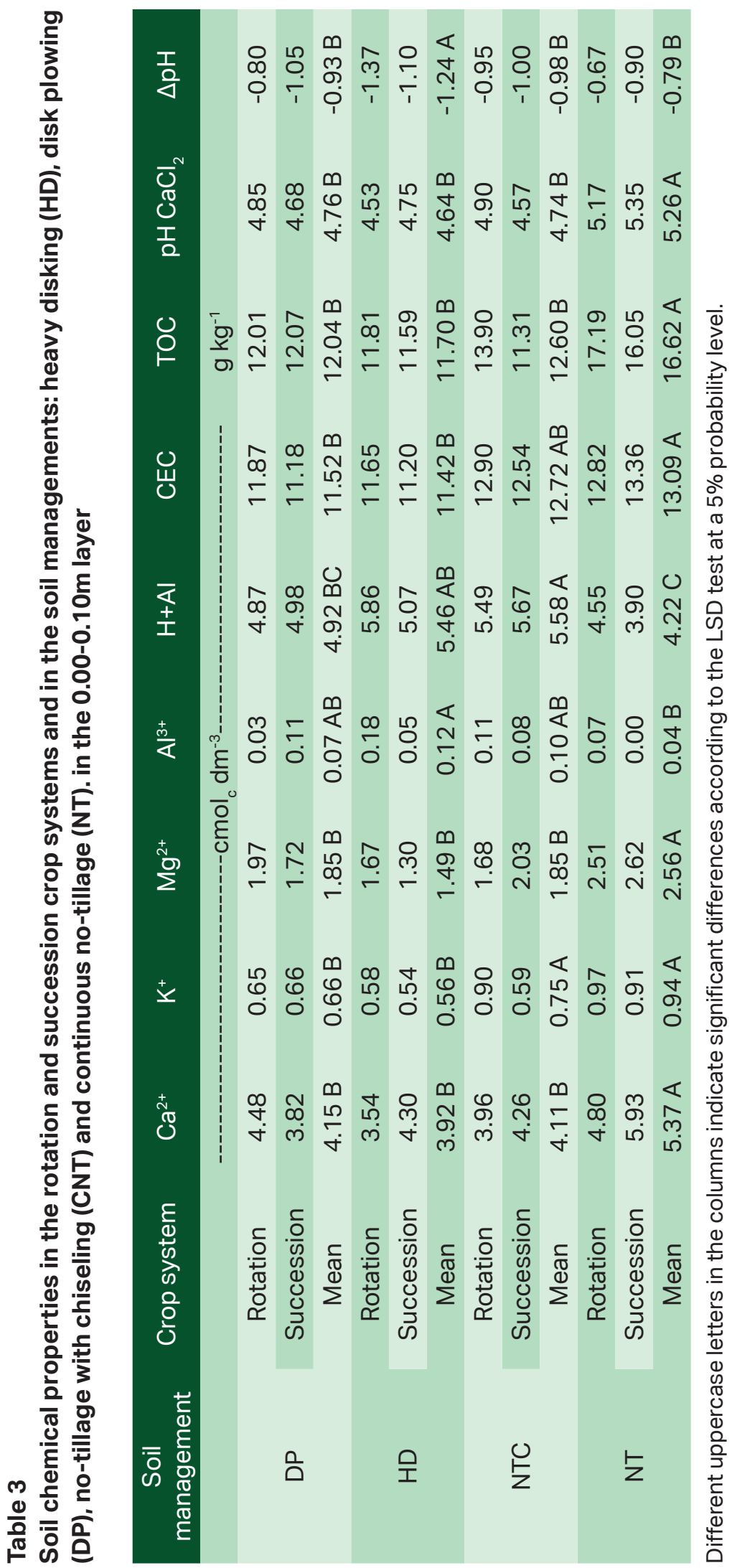


The $\mathrm{H}+\mathrm{Al}$ is inversely correlated to the attributes related to the balance of charges in the soils $(\Delta \mathrm{pH}$ and $\mathrm{pH})$ and the $\mathrm{Ca}^{2+}$ content, without a significant correlation with the TOC,
CEC, $\mathrm{Mg}^{2+}$ and $\mathrm{K}^{+}$(Table 4). In contrast, the TOC is directly correlated to $\mathrm{pH}\left(\mathrm{CaCl}_{2}\right), \mathrm{Ca}^{2+}, \mathrm{Mg}^{2+}$, $\mathrm{K}^{+}$and soil CEC (Table 4).

\section{Table 4}

Correlation between soil potential acidity $(\mathrm{H}+\mathrm{Al})$ and total organic carbon (TOC) with the $\Delta \mathrm{pH}, \mathrm{pH}\left(\mathrm{CaCl}_{2}\right)$, $\mathrm{Ca}^{2+}, \mathrm{Al}^{3+}, \mathrm{Mg}^{2+}, \mathrm{K}^{+}$and $\mathrm{CEC}$ in 0.00-0.10 m layer of a Rhodic Ferralsol, under different soil managements and crop systems $(n=32)$

$\begin{array}{cccccccccc} & \mathrm{TOC} & \mathrm{H}+\mathrm{Al} & \Delta \mathrm{pH} & \mathrm{pH}\left(\mathrm{CaCl}_{2}\right) & \mathrm{Ca}^{2+} & \mathrm{Al}^{3+} & \mathrm{Mg}^{2+} & \mathrm{K}^{+} & \text {CEC } \\ \mathrm{TOC} & 1 & -0.23 & 0.32 & 0.46^{* *} & 0.52^{* *} & -0.26 & 0.50^{* *} & 0.65^{* *} & 0.60^{* *} \\ \mathrm{H}+\mathrm{Al} & -0.23 & 1 & -0.44^{*} & -0.72^{* *} & -0.61^{* *} & 0.43^{*} & -0.23 & -0.27 & 0.09\end{array}$

**Significant at 5\%; and, *Significant at $1 \%$.

\section{Discussion}

The hypothesis that soil management under NT with crop rotation would show the lowest values of DCD was not validated. Crop systems did not affect DCD, and the soil management system NT had the highest values of DCD. Because TOC lowers the DCD values (Carvalho, Fontes, \& Costa, 1998; Melo, Rengasamy, Figueiredo, Barbosa, \& Tavares, 2019), NT with crop rotation, by increasing the TOC values (Table 3), was expected to reduce the DCD. However, DCD was only correlated with $\mathrm{H}+\mathrm{Al}$ (Eq. 1), showing no correlation with TOC (Table 4).

Maintainingsoil coverwithcropresidues while increasing the TOC content in NT may have had the opposite effect to that expected, indirectly promoting clay dispersion. Liming every three years combined with maintaining soil cover with crop residues, releasing alkaline plant extracts and organic acids with acid-base character, may have enhanced clay dispersion in the topsoil layer. The neutralization of the reactivity of clay minerals (oxides and kaolinite) may have overridden the flocculation effect caused by the increase in ionic strength of the soil solution and by the decrease in the diffuse double layer, promoted by cations such as $\mathrm{Al}^{3+}$, $\mathrm{Ca}^{2+}$ and $\mathrm{Mg}^{2+}$.

Higher $\mathrm{H}+\mathrm{Al}$ values in soil management with soil disturbance provided lower DCD values, overriding the flocculation effect of the TOC. Liming decreased $\mathrm{H}+\mathrm{Al}$, thereby possibly neutralizing the positive charges of the iron and aluminum oxides and kaolinite aluminol groups, increasing the repulsion between these minerals (Castro \& Logan, 1991). In addition, the decreased values of exchangeable hydrogen $\left(\mathrm{H}^{+}\right)$and $\mathrm{Al}^{3+}$ neutralization, cations that stabilize the soil structure, have a dispersing action (Morelli \& Ferreira, 1987; Pavan \& Roth, 1992). Increasing the net charge of the particle surfaces increases the thickness of the diffuse double layer of the soil, increasing the repulsion force between particles (Albuquerque, Bayer, 
Ernani, \& Fontana, 2000; Albuquerque, Bayer, Ernani, Mafra, \& Fontana, 2003; Sposito, 2008).

The lowest $\mathrm{H}+\mathrm{Al}$ values on the soil surface under NT most likely resulted from the accumulation of limestone and organic matter (OM) on the soil surface. The surface application of limestone without incorporation causes the accumulation of this corrective on the soil surface (Leite, Galvão, Holanda, Araújo, \& Iwata, 2010), neutralizing the acidity. Furthermore, because this soil management shows higher TOC values (Table 3), the release of alkaline plant extracts, by decomposition of crop residues, and the amphoteric character of the OM may have helped to increase the pH (Diehl, Miyazawa, \& Takahashi, 2008), thus explaining the lowest values of $\mathrm{H}+\mathrm{Al}$. The highest TOC values, which were found in NT, are related to the minimum soil disturbance that occurs under this soil management, which increases the accumulation of crop residues on the surface and reduces OM exposure, thereby reducing its decomposition (Bayer, Mielniczuk, Amado, Martin, \& Fernandes, 2000).

In the crop rotation system, six cycles were repeated, suggesting that these cycles of crop rotation would suffice to increase the diversity of $\mathrm{OM}$, concerning succession, and that they would promote differences in DCD between crop systems due to the effects of mechanical preparation on the soil structure, which depend on the management of crop residues. In addition, the use of black oat in rotation, whose basic plant extract is alkaline $\left(\mathrm{pH}\right.$ 7.2), and higher $\mathrm{K}^{+}$content in solution than in soybean and common wheat extracts used in crop succession (Diehl et al., 2008) could alter interactions between clay particles because of the increases in the $\mathrm{K}^{+}$content and $\mathrm{pH}$ increase the DCD (Ferreira, Tavares,
Ferreira, \& Ralisch, 2010; Homem, Almeida, Condé, Silva, \& Ferreira, 2014). However, in this study, no significant differences in DCD were found between the different crop systems.

NT brings benefits to the soil, such as improved aggregate stability (Singh et al., 2014; Munkholm et al., 2016), attributed to TOC accumulation, which allows the formation of organic bridges between mineral particles (Lee, Schlautman, Toorman, \& Fettweis, 2012), in addition to reducing its wettability (Chenu, Bissonnais, \& Arrouays, 2000). Liming increase the soil $\mathrm{pH}$, neutralizes $\mathrm{Al}^{3+}$ and adds $\mathrm{Ca}^{2+}$ and $\mathrm{Mg}^{2+}$ to the soil surface under NT, improving their chemical fertility (Zandoná, Beutler, Burg, Farias Barreto, \& Schmidt, 2015). However, these changes in soil chemical properties also intensify the charge imbalance in the clay fraction, which, after the impact of raindrops, favors repulsion between particles, thus hindering reflocculation. These findings highlight the importance of not disturbing and of protecting the soil surface in NT to enhance its conservation.

\section{Conclusion}

The degree of clay dispersion is affected by soil management systems with no effect on crop systems. The soil management system with the lowest soil disturbance (continuous no-till) has a higher degree of clay dispersion than the management systems that disturb the soil, regardless of the agricultural implement used or soil disturbance intensity.

The degree of clay dispersion is affected by the soil electrochemical imbalance, primarily caused by the potential soil acidity $(\mathrm{H}+\mathrm{Al})$. 


\section{References}

Abdollahi, L., Schjonning, P., Elmholt, S., \& Munkholm, L. J. (2014). The effects of organic matter application and intensive tillage and traffic on soil structure formation and stability. Soil and Tillage Research, 136, 28-37. doi: 10.1016/j. still.2013.09.011 Retrieved from https:// www.sciencedirect.com/science/article/ pii/S0167198713001797

Albuquerque, J. A., Bayer, C., Ernani, P. R., \& Fontana, E. C. (2000). Propriedades físicas e eletroquímicas de um Latossolo Bruno afetadas pela calagem. Revista Brasileira de Ciência do Solo, 24(2), 295-300. doi: 10.1590/S0100-06832000000200006. Recuperado de https://www.scielo.br/ scielo.php?script=sci_arttext\&pid=S0100 $-06832000000200006$

Albuquerque, J. A., Bayer, C., Ernani, P. R., Mafra, A. L., \& Fontana, E. C. (2003). Aplicação de calcário e fósforo e estabilidade da estrutura de um solo ácido. Revista Brasileira de Ciência do Solo, 27(5), 799-806. doi: 10.1590/S0100$06832003000500004 \quad$ Recuperado de https://www.scielo.br/scielo.php? script=sci_arttext\&pid=S0100-06832003 000500004\&lng =en

Auler, A. C., Caires, E. F., Pires, L. F., Galetto, S. L., Romaniw, J, \& Charnobay, A. C. (2019). Lime effects in a no-tillage system on Inceptisols in Southern Brazil. Geoderma Regional, 16, e00206. doi: 10.1016/j. geodrs.2019.e00206 Retrieved from https://www.sciencedirect.com/science/ article/pii/S23520 09418302815

Barbosa, G.M.C., Oliveira, J.F., Miyazawa, M., Ruiz, D. B., \& Tavares, J., Fo. (2015). Aggregation and Clay dispersion of an Oxisol treated with swine and poultry manures. Soil and Tillage Research, 146(b), 279-285. doi: 10.1016/j.still.2014.09.022 Retrieved from https://www.sciencedirect.com/science/ article/pii/ S0167198714002013

Bayer, C., Mielniczuk, J., Amado, T. J. C., Martin, L., Neto, \& Fernandes, S. V. (2000). Organic matter storage in a sandy clay loam Acrisol affected by tillage and cropping systems in southern Brazil. Soil \& Tillage Research, 54(1-2), 101-109. doi: 10.1016/S01671987(00)00090-8 Retrieved from https:// www.science direct.com/science/article/ pii/S0167198700000908

Camara, R. K., \& Klein, V. A. (2005). Escarificação em plantio direto como técnica de conservação do solo e da água. Revista Brasileira de Ciência do Solo, 29(5), 789-796. doi: 10.1590/ SO100-06832005000500014 Recuperado de https://www.scielo. br/scielo.php?script $=$ sci_arttext \&p $i d=S 0100-06832005000500014$ \& Ing=pt\&nrm=iso

Carvalho, I. A., Fontes, L. E. F., \& Costa, L. M. (1998). Modificações causadas pelo uso e a formação de camada compactada e, ou adensamento em Latossolo Vermelho-Escuro textura média, na região dos cerrados. Revista Brasileira de Ciência do Solo, 22(3), 505-514. doi: 10.1590/S0100-0683199 8000300017 Recuperado de https:// www.scielo.br/scielo.php?script $=$ sci arttext\&pid=S0100-068319980003 00017

Castro, C., Filho, \& Logan, T. J. (1991). Liming effects on the stability and erodibility of some Brazilian Oxisols. Soil Science Society of America Journal, 55(5), 14071413. doi: 10.2136/sssaj1991.03615995 005500050034x Retrieved from https:// acsess.onlinelibrary.wiley.com/doi/ abs/10.2136/sssaj1991.0361599500550 $0050034 \mathrm{x}$ 
Chenu, C., Bissonnais, Y. L., \& Arrouays, D. (2000). Organic matter influence on clay wettability and soil aggregate stability. Soil Science Society of America Journal, 64(4), 1479-1486. doi: 10.2136/sssaj 000. 6441479x Retrieved from https://acsess. onlinelibrary.wiley.com/doi/abs/10.2136/ sssaj2000.6441479x

Claessen, M. E. C., Barreto, W. O., Paula, J. L., \& Duarte, M. N. (1997). Manual de métodos de análise de solo (2a ed. rev. atual.). Rio de Janeiro, RJ: EMBRAPA-CNPS.

Derpsch, R., Friedrich, T., Kassam, A., \& Hongwen, L. (2010). Current status of adoption of no-till farming in the world and some of its main benefits. International Journal of Agricultural and Biological Engineering, 3(1), 1-25. doi: 10.3965/j. issn.1934-6344.2010.01.0-0 Retrieved from https://ijabe.org/index.php/ijabe/ article/view/223

Didoné, E. J., Minella, J. P. G., \& Merten, G. H. (2015). Quantifying soil erosion and sediment yield in a catchment in southern Brazil and implications for land conservation. Journal of Soils and Sediments, 15(11), 2334-2346. doi: 10.1007/s11368-015-1160-0 Retrieved from https://link.springer.com/article/10. 1007/s11368-015-1160-0

Didoné, E. J., Minella, J. P. G., Reichert, J. M., Merten, G. H., Dalbianco, L., Barros, C. P. P. de, \& Ramon, R. (2014). Impact of no-tillage agricultural systems on sediment yield in two large catchment in Southern Brazil. Journal Soil Sediments, 14(7), 12871297. doi: 10.1007/s11368-015-1160-0 Retrieved from https://link. springer.com/ article/10.1007/s11368-013-0844-6

Diehl, R. C., Miyazawa, M., \& Takahashi, H. W. (2008). Compostos orgânicos hidrossolúveis de resíduos vegetais e seus efeitos nos atributos químicos do solo. Revista Brasileira de Ciência do Solo, 32(n. Esp.), 2653-2659. doi: 10.1590/S0100-06832008000700007 Recuperado de https://www.scielo.br/ scielo.php? script=sci_arttext\&pid=S0100 $-06832008000700007$

Federação Brasileira de Plantio Direto e Irrigação (2020). Área sob plantio direto. Recuperado de https:// febrapdp.org.br/ area-de-pd

Ferreira, R. R. M., Tavares, J., Fo., Ferreira, V. M., \& Ralisch, R. (2010). Estabilidade física de solo sob diferentes manejos de pastagem extensiva em cambissolo. Semina: Ciências Agrárias, 31(3), 531-538. doi: 10.5433/1679-0359 Recuperado de http://www.uel.br/revistas/uel/index.php/ semagrarias/article/ view/6490

Findlater, K. M., Kandlikar, M., \& Satterfield, T. (2019). Misunderstanding conservation agriculture: Challenges in promoting, monitoring and evaluating sustainable farming. Environmental Science \& Policy, 100, 47-54. doi: 10.1016/j. envsci.2019.05.027 Retrieved from https://www.sciencedirect.com/science/ article/pii/S1462901118307937

Food and Agriculture Organization of the United Nations (2001). Chapter 1 Introduction: background and objectives. In FAO, The economics of conservation Agriculture (pp. 1-12). Rome: Food and Agriculture Organization of the United Nations. Retrieved from http://www.fao. org/3/y2781e/y2781 e00.htm

Getahun, G. T., Munkholm, L. J., \& Schjonning, P. (2016). The influence of clay-to-carbon ratio on soil physical properties in a humid sandy loam soil with contrasting tillage and residue management. Geoderma, 264(A), 94-102. doi: 10.1016/j. 
geoderma.2015.10.002 Retrieved from https://www. sciencedirect.com/science/ article/pii/S0016706115300975

Homem, B. G. C., Almeida, O. B., Neto, Condé, M. S., Silva, M. D., \& Ferreira, I. M. (2014). Efeito do uso prolongado de água residuária da suinocultura sobre as propriedades químicas e físicas de um Latossolo Vermelho-Amarelo. Científica, Jaboticabal, 42(3), 299-309. doi: 10.15361/1984-5529 Recuperado de http://cientifica.org.br/ index.php/cientifica/article/view/507

Igwe, C. A., \& Obalum, S. E. (2013). Microaggregate stability of tropical soils and its role on soil erosion hazard prediction. In S. Grundas, A. Stepniewski (Eds.), Advances in agrophysical research (pp. 175-192). London: Intechopen.

Igwe, C. A., \& Udegbunam, O. N. (2008). Soil properties influencing water-dispersible clay and silt in an Ultisol in southern Nigeria. International Agrophysics, 22(4), 319-325. Retrieved from http://www. internationalagrophysics.org/Soil-propertiesinfluencing-water-dispersible-clay-andsilt-in-an-Ultisol-in-southern, 106511,0,2. html\#: :text=Soil\%20properties\%20 influencing\%20water\%2Ddispersible, an\%20Ultisol\%20in\%20southern\%20 Nigeria\&text=Soil\%20degradation $\% 20$ such \% 20 as \% 20 soil, (WDC) \% 20 in $\% 20$ the $\% 20$ soil.\&text $=$ Also $\% 20$ water $\% 2$ Ddispersible $\% 20$ silt $\% 20$ (WDSi,of\%2066.5\%20g\%20kg\%2D1

IUSS Working Group WRB (2015). World reference base for soil resources 2014, update 2015. International soil classification system for naming soils and creating legends for soil maps. Rome: FAO.

Kassam, A., Friedrich, T., \& Derpsch, R. (2019). Global spread of conservation agriculture. International Journal of
Environmental Studies, 76(1), 29-51. doi: $\quad 10.1080 / 00207233.2018 .1494927$ Retrieved from https://www.tandfonline. com/doi/abs/10.1080/00207233.2018.14 94927?journalCode=genv20

Lee, B. J., Schlautman, M. A., Toorman, E., \& Fettweis, M. (2012). Competition between kaolinite flocculation and stabilization in divalent cation solutions with anionic polyacrylamides. Water Research, 46(17), 5696-5706. doi: 10.1016/j. watres.2012.07.056 Retrieved from https://www.sciencedirect.com/science/ article/pii/S0043135412005507

Leite, L. F. C., Galvão, S. R. S., Holanda, M. R., Neto, Araújo, F. S., \& Iwata, B. F. (2010). Atributos químicos e estoques de carbono em Latossolo sob plantio direto no cerrado do Piauí. Revista Brasileira de Engenharia Agrícola e Ambiental, 14(12), 1273-1280. doi: 10.1590/S1415-43662010001200004 Recuperado de https://www.scielo.br/ scielo.php?script=sci_arttext\&pid=S1415 $-43662010001200004$

Lipiec, J., Czyżb, E. A., Dexter, C. A. R., \& Siczeka, A. (2018). Effects of soil deformation on clay dispersion in loess soil. Soil \& Tillage Research, 184, 203-206. doi: 10.1016/j. still.2018.08.005 Retrieved from https:// www.sciencedirect.com/science/article/ pii/S0167198718304628

Machado, W., Melo, T. R., \& Tavares, J., Fo. (2017). Clay dispersion and loss in Oxisol treated with diferent concentrations of limestone. Semina: Ciências Agrárias, 38(6), 39073914. doi: 10.5433/1679-0359 Retrieved from http://www.uel.br/revistas/uel/index. php/semagrarias/article/view/28643

Melo, T. R., Rengasamy, P., Figueiredo, A., Barbosa, G. M. C., \& Tavares, J., Fo. (2019). A new approach on the structural stability 
of soils: Method proposal. Soil \& Tillage Research, 193, 171-179. doi: 10.1016/j. still.2019.04.013 Retrieved from https:// www.sciencedirect.com/science/article/ pii/S01671987183133 08?via\%3Dihub

Melo, T. R., Telles, T. S., Machado, W. S., \& Tavares, J., $F^{\circ}$. (2016). Factors affecting clay dispersion in Oxisols treated with vinasse. Semina: Ciências Agrárias, 37(6), 3997-4004. doi: 10.5433/1679-0359 Retrieved from http://www.uel.br/revistas/ uel/index.php/semagrarias/article/ viewFile/26487/20049

Merten, G. H., Araújo, A. G., Biscaia, R. C. M., Barbosa, G. M. C., \& Conte, O. (2015). No-till surface runoff and soil losses in southern Brazil. Soil and Tillage Research, 152, 85-93. doi: 10.1016/j. still.2015.03.014 Retrieved from https:// www.sciencedirect.com/science/article/ pii/S0167198715000823

Merten, G. H., \& Minella, J. P. G. (2013). The expansion of Brazilian agriculture: soil erosion scenarios. International Soil and Water Conservation Research, 1(3), 37-48. doi: 10.1016/S20956339(15)30029-0 Retrieved from https:// www.sciencedirect.com/science/article/ pii/S2095633915300290

Morelli, M., \& Ferreira, E. B. (1987). Efeito do carbonato de cálcio e do fosfato diamônico em propriedades eletroquímicas e físicas de um Latossolo. Revista Brasileira de Ciência do Solo, 11(2), 1-6. doi: 10.1590/S0100-06832000000200006. Recuperado de https://www.scielo.br/ scielo.php?script=sci_arttext\&pid=S0100 $-06832000000200006$

Munkholm, L. J., Heck, R. J., Deen, B., \& Zidar, T. (2016). Relationship between soil aggregate strength, shape and porosity for soils under different long-term management. Geoderma, 268, 52-59. doi: $\quad$ 10.1016/j.geoderma.2016.01.005 Retrieved from https://www.sciencedirect. com/science/article/pii/S00167061163 00052

Nguetnkam, J. P., \& Dultz, S. (2014). Clay dispersion in typical soils of north cameroon as a function of $\mathrm{pH}$ and electrolyte concentration. Land Degradation \& Development, 25(2), 153162. doi: 10.1002/ldr.1155 Retrieved from https://onlinelibrary.wiley.com/doi/ full/10.1002/ldr.1155

Palm, C., Blanco-Canqui, H., De Clerck, F., Gatere, L., \& Grace, P. (2014). Conservation agriculture and ecosystem services: an overview. Agriculture Ecosystem Environment, 187, 87-105. doi: 10.1016/j. agee. 2013.10.010 Retrieved from https:// www.sciencedirect.com/science/article/ piiS01678809130035 02

Pavan, M. A., Bloch, M. D. M., Zemoulski, H. C., Miyazawa, M., \& Zocoler, D. C. (1992). Manual de análises químicas de solo e controle de qualidade. (Circular Técnica, 76). Londrina: Instituto Agronômico do Paraná.

Pavan, M. A., \& Roth, C. H. (1992). Effect of lime and gypsum on chemical composition of runoff and leachate from samples of a Brazilian Oxisol. Ciência e Cultura, 44(6), 391-394. doi: 10.1016/0016-7061(91) 90053-V

Pittelkow, C. M., Liang, X., Linquist, B. A., van Groeningen, K. J., Lee, J., Lundy, M. E.,... van Kessel, C. (2015). Productivity limits and potentials of the principles of conservation agriculture. Nature (Letter), 517, 365-368. doi: 10.1038/nature13809 Retrieved from https://www.nature.com/ articles/nature13809 
Rengasamy, P., Tavakkoli, E., \& Mcdonald, G. K. (2016). Exchangeable cations and clay dispersion: net dispersive charge, a new concept for dispersive soil. European Journal of Soil Science, 67(5), 1-7. doi: 10.1111/ejss.12369. Retrieved from https://onlinelibrary.wiley.com/doi/ full/10.1111/ejss.12369

Santos, H. G., Jacomine, P. K. T., Anjos, L. H. C. D., Oliveira, V. A. D., Lumbreras, J. F., Coelho, M. R.,... Oliveira, J. B. D. (2013). Sistema brasileiro de classificação de solos. Brasília, DF: EMBRAPA.

Singh, A., Phogat, V. K., Dahiya, R., \& Batra, S. D. (2014). Impact of long-term zero till wheat on soil physical properties and wheat productivity under ricewheat cropping system. Soil \& Tillage Research, 140, 98-105. doi: 10.1016/j. still.2014.03.002 Retrieved from https:// www.sciencedirect.com/science/ article/pii/S0167198714000373\#: : text=Long \%2Dterm \%20impact $\% 20$ of\%20zero,rice\%E2\%80\%93wheat\%20 $\mathrm{s}$ y s t e m \% $20 \mathrm{w}$ a s \% 20 e v a I u a t ed. \& t ext $=\mathrm{S}$ o il \% 20 OC\%2C\%20aggregation\%2C\%20root \% 20 penetration, and \% 20 sub $\% 2$ Dsoil $\% 20$ compaction $\% 20$ reduced.\&text $=$ Effect $\% 20$ was $\% 20$ variable\%20with\%20depth\%20and\%20 in\%20magnitude\%20in\%20different\%20 textured $\% 20$ soils.\&text=Improved $\% 20$ conditions $\% 20$ increased $\% 20$ wheat $\% 20$ productivity $\% 20$ significant $\% 20$ in $\% 20$ clay\%20loam\%20soil
Sposito, G. (2008). The chemistry of soils (2a ed.). New York: Oxford University Press.

Tavares, J., Fo., Barbosa, G. M. C., \& Ribon, A. A. (2010). Water-dispersible clay in soils treated with sewage sludge. Revista Brasileira de Ciência do Solo, 34(5), 15271534. doi: 10.1590/S0100-06832010000 500005 Retrieved from https://www. scielo.br/scielo.php?script=sci_ abstract\&pid=S0100-068320100005 00005\&lng $=e \& n r m=i s o$

Telles, T. S., Righetto, A. J., Costa, G. V., Volsi, B., \& Oliveira, J. F. (2019). Conservation agriculture practices adopted in southern Brazil. International Journal of Agricultural Sustainability, 17(5), 338-346. doi: $\quad 10.1080 / 14735903.2019 .1655863$ Retrieved from https://www.tandfonline. com/doi/abs/10.1080/14735903.2019. 1655863

Zandoná, R. R., Beutler, A. N., Burg, G. M., Farias Barreto, C., \& Schmidt, M. R. (2015). Gesso e calcário aumentam a produtividade e amenizam o efeito do déficit hídrico em milho e soja. Pesquisa Agropecuária Tropical, 45(2), 128-137. Retrieved from https://www.revistas.ufg.br/pat/article/ view/30301\#: :text=Durante\%200\%20 cultivo\%20de\%20milho,mitigar $\% 20$ a s \% 20 perda s\% 20 n a \% 20 produtividade. \&text=Atributos $\% 20$ q u \% C $3 \%$ A D m i c o s \% 20 d o \% 20 solo $\% 20$ e $\% 20 a \% 20$ produtividade $\% 20$ de $\% 20$ gr \% C 3\%A3 os,e \% 20 de $\% 20$ soja\%20foram\%20avaliados 